\title{
Fixed-bed-column Studies in Laboratory and Pilot Scale for Methylene Blue Removal and Recovery by Untreated, Autohydrolized and Brine Hydrolized Spruce
}

\author{
Odysseas Kopsidas \\ Laboratory of Simulation of Industrial Processes, Department of Industrial Management and Technology, University of Piraeus, \\ Piraeus 18534, Greece
}

\begin{abstract}
This work reports the practicability of using spruce to remove widely-used basic dyes, like Methylene Blue from wastewaters. In continuous fixed-bed column systems, the effects of parameters, such as bed-depth, flow rate and initial dye concentration, were examined. The results revealed that the Methylene Blue is fairly adsorbed on spruce. This process could be a low-cost technique for the removal of basic dyes from aqueous systems.
\end{abstract}

Key words: Adsorption, desorption, column, methylene blue, spruce.

\section{Introduction}

This work aims at the analytical presentation of the adsorption systems, reactors and the design methods of the fixed-bed or packed-column biomass. Initially, the definitions are given about fixed-bed or packed-bed systems and/or reactors [1]. Then, the physical characteristics of the fixed-bed columns are presented [2]. Both ends, low, medium and high scale (laboratory and pilot) individual experiments are combined to provide a basis for scale up modeling. Next, the scale up or modeling of dye removal systems is thoroughly analyzed [3]. The vast majority of existing mathematical models for similar systems are referring to the removal of heavy metals, organic toxicants, etc. from wastewater or from natural water systems (lake, river, sea, surface, underground) [4]. In this study, continuous fixed-bed-column systems were investigated [5]. The adsorbents which we use are spruce (Picea Abies) untreated and spruce modified by autohydrolysis [6]. The column systems were filed with biomass at various

Corresponding author: Odysseas Kopsidas, Ph.D., main research field: environmental technology. initial dye concentrations, flow rates and bed-depths [7].

\section{Materials and Methods}

The used spruce (Picea Abies) sawdust was obtained from a local furniture manufacturing company, as a suitable source for full-scale/industrial applications. The moisture content of the material when received was $9 \%(\mathrm{w} / \mathrm{w})$; after screening, the fraction with particle sizes between $0.2 \mathrm{~mm}$ and $0.9 \mathrm{~mm}$ was isolated.

The dye used herein in batch and column experiments was Methylene Blue (C16H18ClN3S. $3 \mathrm{H}_{2} \mathrm{O}$, molecular weight $=373.90 \times 10^{-3} \mathrm{~kg} \cdot \mathrm{mol}^{-1}$ ) supplied by Sigma-Aldrich. A stock solution was prepared by dissolving a specific amount of MB (humidity 22\%) in distilled water. Working solutions were $3-140 \mathrm{mg} \cdot \mathrm{L}^{-1}$. MB concentrations were determined by measuring the absorbent values in each experiment with $\mathrm{HACH}$ DR4000U UV-VIS spectrophotometer at $\lambda=664 \mathrm{~nm}$.

The autohydrolysis process was performed in a 3.75 L batch reactor PARR 4843. The isothermal autohydrolysis time was that $\mathrm{t}=0,10,20,30,40$ and 

Untreated, Autohydrolized and Brine Hydrolized Spruce

50 min (not including the non-isothermal preheating and the cooling time-periods); the reaction was catalyzed by the organic acids produced by the pine sawdust itself during autohydrolysis at a liquid-to-solid ratio of 10:1; the liquid phase volume (water) was 2,000 $\mathrm{mL}$ and the solid material dose (pine sawdust) was $200 \mathrm{~g}$; stirring speed was $150 \mathrm{rpm}$. The final temperature values of the reaction were $\mathrm{T}=160^{\circ} \mathrm{C}$, $200{ }^{\circ} \mathrm{C}$ and $240{ }^{\circ} \mathrm{C}$, reached after the preheating time values of $\mathrm{t}=42,62$ and $80 \mathrm{~min}$, respectively. The autohydrolysis product was filtered using a Buchner filter with Munktell paper sheet (grade 34/N) to separate the liquid phase and from the solid phase. The solid residue was washed with water until neutral $\mathrm{pH}$ (the initial filtrate $\mathrm{pH}$ ) was 2.90-4.76 depending on the autohydrolysis severity. The solid residue was dried at $110{ }^{\circ} \mathrm{C}$ for 10 days at room temperature to reach the humidity of the untreated material. Then it was used as adsorbent. Table 1 shows the adsorption by autohydrolized spruce.

The brine treatment process was performed in a 3.75 $\mathrm{L}$ batch reactor PARR 4843. The isothermal autohydrolysis time was $\mathrm{t}=0,10,20,30,40$ and 50 min (not including the non-isothermal preheating and the cooling time-periods); the reaction was catalyzed by the organic acids produced by the pine sawdust itself during autohydrolysis at a liquid-to-solid ratio of 10:1; the liquid phase volume (water) was $2,000 \mathrm{~mL}$ and the solid material dose (pine sawdust) was $200 \mathrm{~g}$; the stirring speed was $150 \mathrm{rpm}$. The final temperature values fo the reaction were $\mathrm{T}=160{ }^{\circ} \mathrm{C}, 200{ }^{\circ} \mathrm{C}$ and
$240{ }^{\circ} \mathrm{C}$, reached after the preheating time values $\mathrm{t}=42$, 62 and $80 \mathrm{~min}$, respectively. The autohydrolysis product was filtered using a Buchner filter with Munktell paper sheet (grade $34 / \mathrm{N}$ ) to separate the liquid phase and from the solid phase. The solid residue was washed with water until neutral $\mathrm{pH}$ (the initial filtrate $\mathrm{pH}$ ) was 2.90-4.76 depending on the autohydrolysis severity. The solid residue was dried at $110{ }^{\circ} \mathrm{C}$ for 10 days at room temperature to reach the humidity of the untreated material. Then it was used as adsorbent. In Table 2 it is shown the adsorption by brine hydrolyzed spruce.

The column can be filled with random dumped packing (creating a "random packed column") or with structured packing sections, which are arranged or stacked (creating a "stacked packed column"). In the column, liquids tended to wet the surface of the packing and the vapors pass across this wetted surface, where mass transfer takes place [1, 2]. Packing material can be used instead of trays to improve separation in distillation columns. Packing offers the advantage of a lower pressure drop across the column (when compared to plates or trays), which is beneficial while operating under vacuum. Differently shaped packing materials have different surface areas and void space between the packing. Both of these factors affect packing performance $[3,4]$.

Packed columns are most frequently used to remove contaminants from a gas stream (adsorption) $[5,6]$. However, packed columns can also be used to remove volatile components from a liquid stream by contacting

Table 1 Adsorption by autohydrolized spruce.

\begin{tabular}{lllllllll}
\hline $\mathrm{T}\left({ }^{\circ} \mathrm{C}\right)$ & $\mathrm{t}(\mathrm{min})$ & $\mathrm{Ci}$ & $\mathrm{Q}(\mathrm{mL} / \mathrm{min})$ & $\mathrm{m}(\mathrm{g})$ & $\mathrm{N}$ & $\mathrm{K}$ & $\mathrm{R}$ & $\mathrm{qo}(\mathrm{mg} / \mathrm{g})$ \\
\hline 160 & 0 & 165 & 20 & 20 & 9,643 & 0.000146 & -0.9313 & 43.01 \\
160 & 0 & 165 & 20 & 20 & 6,492 & 0.000541 & -0.9651 & 28.96 \\
160 & 20 & 165 & 20 & 20 & 6,362 & 0.000449 & -0.9573 & 28.38 \\
160 & 30 & 165 & 20 & 20 & 7,176 & 0.000381 & -0.9325 & 32.01 \\
160 & 40 & 165 & 20 & 20 & 6,092 & 0.000596 & -0.9779 & 27.17 \\
160 & 50 & 165 & 20 & 20 & 10,412 & 0.000193 & -0.8966 & 46.44 \\
180 & 10 & 165 & 20 & 20 & 6,926 & 0.000371 & -0.9740 & 30.89 \\
240 & 30 & 165 & 20 & 20 & 7,355 & 0.000229 & -0.9551 & 41.06 \\
240 & 50 & 165 & 20 & 20 & 5,389 & 0.000275 & -0.9813 & 28.38 \\
\hline
\end{tabular}


Fixed-bed-column Studies in Laboratory and Pilot Scale for Methylene Blue Removal and Recovery by 49 Untreated, Autohydrolized and Brine Hydrolized Spruce

Table 2 Adsorption by brine hydrolyzed spruce.

\begin{tabular}{lllllllllll}
\hline $\begin{array}{l}\text { Conc. } \mathrm{X} \\
\text { Times }\end{array}$ & $\mathrm{T}\left({ }^{\circ} \mathrm{C}\right)$ & $\mathrm{t}(\mathrm{min})$ & $\mathrm{Ci}$ & $\begin{array}{l}\mathrm{Q} \\
(\mathrm{mL} / \mathrm{min})\end{array}$ & $\mathrm{x}(\mathrm{cm})$ & $\mathrm{m}(\mathrm{g})$ & $\mathrm{N}$ & $\mathrm{K}$ & $\mathrm{R}$ & $\mathrm{qo}(\mathrm{mg} / \mathrm{g})$ \\
\hline 1 & 180 & 50 & 165 & 20 & 15 & 20 & 4,948 & 0.000353 & -0.9481 & 18.21 \\
2 & 180 & 50 & 165 & 20 & 15 & 20 & 6,975 & 0.000242 & -0.9683 & 25.67 \\
4 & 140 & 0 & 165 & 20 & 15 & 20 & 8,461 & 0.000153 & -0.9616 & 51.42 \\
4 & 160 & 0 & 165 & 20 & 15 & 20 & 4,304 & 0.000694 & -0.9946 & 27.07 \\
4 & 160 & 50 & 165 & 20 & 15 & 20 & 5,834 & 0.000300 & -0.9662 & 21.47 \\
4 & 180 & 0 & 165 & 20 & 15 & 20 & 6,054 & 0.000257 & -0.9744 & 38.41 \\
4 & 180 & 50 & 165 & 20 & 15 & 20 & 5,666 & 0.000444 & -0.9479 & 20.85 \\
4 & 200 & 0 & 165 & 20 & 15 & 20 & 4,682 & 0.000866 & -0.9667 & 28.01 \\
4 & 200 & 50 & 165 & 20 & 15 & 20 & 9,259 & 0.000132 & -0.9390 & 46.67 \\
4 & 200 & 50 & 165 & 20 & 15 & 20 & 7,713 & 0.000157 & -0.9232 & 28.38 \\
4 & 220 & 50 & 165 & 20 & 15 & 20 & 5,840 & 0.000235 & -0.9863 & 35.82 \\
4 & 200 & 50 & 165 & 20 & 15 & 20 & 9,233 & 0.000181 & -0.9466 & 33.97 \\
4 & 240 & 50 & 165 & 20 & 15 & 20 & 1,358 & 0.000899 & -0.9237 & 7.69 \\
4 & 240 & 50 & 165 & 20 & 15 & 20 & 451 & 0.000369 & -0.7918 & 2.76 \\
4 & 240 & 50 & 165 & 20 & 15 & 20 & 451 & 0.000369 & -0.7918 & 2.76 \\
8 & 180 & 0 & 165 & 20 & 15 & 20 & 4,715 & 0.000212 & -0.9565 & 28.92 \\
8 & 180 & 50 & 165 & 20 & 15 & 20 & 7,089 & 0.000351 & -0.9211 & 30.16 \\
8 & 180 & 50 & 165 & 20 & 15 & 20 & 5,695 & 0.000259 & -0.9799 & 20.96 \\
\hline
\end{tabular}

it with an inert gas (stripping). They are also used in distillation applications where the separation is particularly difficult due to close boiling components [7].

The concentration of output solution was measured at $\lambda=664 \mathrm{~nm}$ and using HACH DR4000U UV-vis spectrophotometer. Finally, $\mathrm{pH}$ measurements were made using a digital $\mathrm{pH}$ meter, MultiLab model 540.

\section{Results and Discussion}

Bohart and Adams came up with the Bohart-Adams (B-A) model when they proceeded with their work of analyzing the typical chlorine charcoal transmission curve $[8,9]$. A widely used continuous fixed-bed-column model was established by Bohart and Adams, who assumed that the rate of adsorption is controlled by the surface binding (through chemical reaction or physical interaction) between adsorbate and unused capacity of the solid, i.e., adsorption rate $=$ $\mathrm{K} \cdot \mathrm{C} \cdot \mathrm{Cu}$, where $\mathrm{K}$ is the adsorption rate coefficient, $\mathrm{C}$ is the adsorbate concentration at the solid phase at distance $\mathrm{x}$, and $\mathrm{Cu}$ is the unused surface adsorptive capacity at time $t$, expressed as mass per volume of bed
$[10,12]$. The material balance for adsorbate is given by the partial differential equation:

$$
\frac{\partial C_{u}}{\partial t}=-K \cdot C \cdot C_{u}
$$

while the corresponding partial differential equation for the $\mathrm{Cu}$ decrease is

$$
\frac{\partial C}{\partial x}=-\frac{K}{u} \cdot C \cdot C_{u}
$$

where $\mathrm{u}$ is the superficial liquid velocity. These equations are obtained neglecting diffusion and accumulation terms, assumptions that are valid in chemical engineering practice, provided that strict scale up specifications are kept in the design stage and successful operation conditions are kept in the industrial operation stage [13].

The differential equations can be integrated over the total length $\mathrm{x}$ of the bed to give:

$$
\ln \left(\frac{C_{i}}{C}-1\right)=\ln \left[\exp \left(\frac{K . N . x}{u}\right)-1\right]-K \cdot C_{i} \cdot t
$$

here $\mathrm{N}\left(\mathrm{mg} \cdot \mathrm{L}^{-1}\right)$ is the initial or total adsorption capacity coefficient, also quoted as $\mathrm{CuO}$ [14]; $\mathrm{C}=$ 
effluent concentration $\left(\mathrm{mg} \cdot \mathrm{L}^{-1}\right) ; \quad \mathrm{C}_{\mathrm{i}}=$ influent concentration $\left(\mathrm{mg} \cdot \mathrm{L}^{-1}\right) ; \mathrm{K}=$ adsorption rate coefficient $\left(\mathrm{L} \cdot \mathrm{mg}^{-1} \cdot \mathrm{min}^{-1}\right) ; \mathrm{x}=$ bed depth $(\mathrm{cm}) ; \mathrm{u}=$ linear velocity $\left(\mathrm{cm} \cdot \mathrm{min}^{-1}\right)$; and $\mathrm{t}=$ time $(\mathrm{min})$. Since $\exp (K . N . x / u)$ is usually much greater than unity, this equation can be simplified to:

$$
\ln \left(\frac{C_{i}}{C}-1\right)=\frac{K \cdot N \cdot x}{u}-K \cdot C_{i} \cdot t
$$

which is commonly used by researchers, because of its convenience in estimating the values of parameters $\mathrm{K}$ and $\mathrm{N}$ through linear regression either of $\ln \left[\left(\mathrm{C}_{0} / \mathrm{C}_{\mathrm{i}}\right)-1\right]$ vs $\mathrm{t}$ or $\mathrm{t}$ vs $\mathrm{x}$ when the following rearrangement is adopted:

$$
t=\frac{N \cdot x}{C_{i} \cdot u}-\frac{1}{K \cdot C_{i}} \cdot\left(\ln \frac{C_{i}}{C}-1\right)
$$

In this rearrangement, $t$ is the time to breakthrough, i.e., the time period required for concentration to reach a predetermined value. For using the last expression as a linear regression model, wastewater is passed through beds of varying depths, keeping constant $\mathrm{C}_{\mathrm{i}}$ and $\mathrm{u}$, preferably at values similar to those expected to prevail under real conditions at full scale. Alternatively, it can be performed by the aid of at least three columns arranged in series. In such a case, sampling takes place at the bottom of each column and measured for adsorbate concentration, making more frequent measurements when approaching the breakthrough concentration C [15]. Finally, the time at which the effluent reaches this concentration is used as the dependent variable while $\mathrm{x}$ plans the role of the independent one. Evidently, the use of such a regression model implies the additional error of measuring the independent variable with less precision in comparison with the dependent. The common error in both models comes from the estimation of concentration from measuring adsorbance although the reference relation/curve has been structured/drawn in the inverse mode, i.e., for predetermined concentrations, the corresponding adsorbances have been measured.

In the present work, the model of Eq. (4) has been used for parameter values estimation through linear regression to obtain numerical results comparable with corresponding data found for other fixed bed adsorption studies in literature. The non-linear form of this model is:

$$
C=\frac{C_{i}}{1+A e^{-r t}}
$$

where $A=e^{K \cdot N \cdot x / u} ; r=K \cdot C_{i}$. The model of Eq. (6) has been used for parameter values estimation through NLRA to obtain more reliable numerical results, i.e., with a lower total standard error of estimate (SEE). In the last curve, the regression model is written under the form for parameter identification through $\mathrm{Ci}$ value estimation (a) endogenously and exogenously.

On the other hand, Clark [16] has advanced the Bohart and Adams model [15] by incorporating the parameter, n, of the Freundlich adsorption isotherm:

$$
C=\left[\frac{C_{i}^{n-1}}{1+A e^{-r t}}\right]^{\frac{1}{n-1}}
$$

where $n=$ inverse of the slope of the Freundlich isotherm [16]. Finally, the Bohart and Adams model [17] can be reduced for $n=2$ from Clark model [16-18]. In Table 3 it is shown the fixed bed column systems for spruce.

In this study, continuous fixed-bed-column systems were investigated. The column systems were filed with spruce at various initial dye concentrations, flow rates and bed-depths. In Table 4, it is shown the fixed bed column systems for spruce modified by autohydrolysis.

In Table 5, it is shown the fixed bed column systems for spruce modified by brine treatment.

In Table 6, it is shown the adsorption by untreated spruce.

In Table 7, it is shown the adsorption by untreated spruce. 
Table 3 Fixed-bed-column systems for spruce.

\begin{tabular}{llllllll}
\hline $\mathrm{Ci}$ & $\mathrm{Q}(\mathrm{mL} / \mathrm{min})$ & $\mathrm{x}(\mathrm{cm})$ & $\mathrm{m}(\mathrm{g})$ & $\mathrm{N}$ & $\mathrm{K}$ & $\mathrm{R}$ & $\mathrm{qo}(\mathrm{mg} / \mathrm{g})$ \\
\hline 160 & 20 & 15 & 12 & 6,683 & 0.000318 & -0.9506 & 40.99 \\
160 & 20 & 15 & 12 & 7,400 & 0.000100 & -0.9367 & 45.38 \\
160 & 20 & 15 & 13 & 6,507 & 0.000356 & -0.9992 & 36.84 \\
160 & 20 & 15 & 13 & 6,387 & 0.000518 & -0.9539 & 36.16 \\
160 & 20 & 15 & 13 & 6,387 & 0.000518 & -0.9539 & 36.16 \\
160 & 20 & 15 & 15 & 5,329 & 0.000416 & -0.9153 & 26.14 \\
160 & 20 & 15 & 19 & 5,274 & 0.000415 & -0.9457 & 20.16 \\
160 & 20 & 15 & 19 & 5,274 & 0.000415 & -0.9457 & 20.16 \\
160 & 20 & 15 & 20 & 9,248 & 0.000110 & -0.9530 & 19.19 \\
160 & 20 & 15 & 20 & 8,738 & 0.000216 & -0.9765 & 32.15 \\
160 & 40 & 15 & 20 & 4,459 & 0.000515 & -0.9903 & 16.41 \\
160 & 40 & 25 & 34 & 5,320 & 0.000347 & -0.9892 & 19.19 \\
160 & 20 & 25 & 34 & 6,154 & 0.000243 & -0.9870 & 22.20 \\
80 & 40 & 25 & 34 & 4,480 & 0.000689 & -0.9911 & 16.16 \\
\hline
\end{tabular}

Table 4 Fixed-bed-column systems for spruce modified by autohydrolysis $(x=15 \mathrm{~cm})$.

\begin{tabular}{lllllllll}
\hline $\mathrm{T}\left({ }^{\circ} \mathrm{C}\right)$ & $\mathrm{t}(\mathrm{min})$ & $\mathrm{Ci}$ & $\mathrm{Q}(\mathrm{mL} / \mathrm{min})$ & $\mathrm{m}(\mathrm{g})$ & $\mathrm{N}$ & $\mathrm{K}$ & $\mathrm{R}$ & $\mathrm{qo}(\mathrm{mg} / \mathrm{g})$ \\
\hline 160 & 0 & 160 & 20 & 16.5 & 9,643 & 0.000146 & -0.9313 & 43.01 \\
160 & 0 & 160 & 20 & 16.5 & 6,492 & 0.000541 & -0.9651 & 28.96 \\
160 & 20 & 160 & 20 & 16.5 & 6,362 & 0.000449 & -0.9573 & 28.38 \\
160 & 30 & 160 & 20 & 16.5 & 7,176 & 0.000381 & -0.9325 & 32.01 \\
160 & 40 & 160 & 20 & 16.5 & 6,092 & 0.000596 & -0.9779 & 27.17 \\
160 & 50 & 160 & 20 & 16.5 & 10,412 & 0.000193 & -0.8966 & 46.44 \\
180 & 10 & 160 & 20 & 16.5 & 6,926 & 0.000371 & -0.9740 & 30.89 \\
240 & 30 & 160 & 20 & 13.81 & 7,355 & 0.000229 & -0.9551 & 41.06 \\
240 & 50 & 160 & 20 & 14.16 & 5,389 & 0.000275 & -0.9813 & 28.38 \\
\hline
\end{tabular}

Table 5 Fixed-bed-column systems for spruce modified by brine treatment.

\begin{tabular}{|c|c|c|c|c|c|c|c|c|c|c|}
\hline $\begin{array}{l}\text { Concen } \\
\text { trated X } \\
\text { Times } \\
\end{array}$ & $\mathrm{T}\left({ }^{\circ} \mathrm{C}\right)$ & $\mathrm{t}(\min )$ & $\mathrm{Ci}$ & $\begin{array}{l}\mathrm{Q} \\
(\mathrm{mL} / \mathrm{min})\end{array}$ & $\mathrm{x}(\mathrm{cm})$ & $\mathrm{m}(\mathrm{g})$ & $\mathrm{N}$ & $\mathrm{K}$ & $\mathrm{R}$ & qo $(\mathrm{mg} / \mathrm{g})$ \\
\hline 1 & 180 & 50 & 165 & 20 & 15 & 20 & 4,948 & 0.000353 & -0.9481 & 18.21 \\
\hline 2 & 180 & 50 & 165 & 20 & 15 & 20 & 6,975 & 0.000242 & -0.9683 & 25.67 \\
\hline 4 & 140 & 0 & 165 & 20 & 15 & 12.11 & 8,461 & 0.000153 & -0.9616 & 51.42 \\
\hline 4 & 160 & 0 & 165 & 20 & 15 & 11.7 & 4,304 & 0.000694 & -0.9946 & 27.07 \\
\hline 4 & 160 & 50 & 165 & 20 & 15 & 20 & 5,834 & 0.000300 & -0.9662 & 21.47 \\
\hline 4 & 180 & 0 & 165 & 20 & 15 & 11.6 & 6,054 & 0.000257 & -0.9744 & 38.41 \\
\hline 4 & 180 & 50 & 165 & 20 & 15 & 20 & 5,666 & 0.000444 & -0.9479 & 20.85 \\
\hline 4 & 200 & 0 & 165 & 20 & 15 & 12.3 & 4,682 & 0.000866 & -0.9667 & 28.01 \\
\hline 4 & 200 & 50 & 165 & 20 & 15 & 14.6 & 9,259 & 0.000132 & -0.9390 & 46.67 \\
\hline 4 & 200 & 50 & 165 & 20 & 15 & 20 & 7,713 & 0.000157 & -0.9232 & 28.38 \\
\hline 4 & 220 & 50 & 165 & 20 & 15 & 12 & 5,840 & 0.000235 & -0.9863 & 35.82 \\
\hline 4 & 200 & 50 & 165 & 20 & 15 & 20 & 9,233 & 0.000181 & -0.9466 & 33.97 \\
\hline 4 & 240 & 50 & 165 & 20 & 15 & 13 & 1,358 & 0.000899 & -0.9237 & 7.69 \\
\hline 4 & 240 & 50 & 165 & 20 & 15 & 12 & 451 & 0.000369 & -0.7918 & 2.76 \\
\hline 4 & 240 & 50 & 165 & 20 & 15 & 12 & 451 & 0.000369 & -0.7918 & 2.76 \\
\hline 8 & 180 & 0 & 165 & 20 & 15 & 12 & 4,715 & 0.000212 & -0.9565 & 28.92 \\
\hline 8 & 180 & 50 & 165 & 20 & 15 & 17.3 & 7,089 & 0.000351 & -0.9211 & 30.16 \\
\hline 8 & 180 & 50 & 165 & 20 & 15 & 20 & 5,695 & 0.000259 & -0.9799 & 20.96 \\
\hline
\end{tabular}


494 Fixed-bed-column Studies in Laboratory and Pilot Scale for Methylene Blue Removal and Recovery by Untreated, Autohydrolized and Brine Hydrolized Spruce

Table 6 Adsorption by untreated spruce.

\begin{tabular}{|c|c|c|c|c|c|c|c|}
\hline $\mathrm{Ci}$ & $\mathrm{Q}(\mathrm{mL} / \mathrm{min})$ & $\mathrm{x}(\mathrm{cm})$ & $\mathrm{m}(\mathrm{g})$ & $\mathrm{N}$ & $\mathrm{K}$ & $\mathrm{R}$ & qo $(\mathrm{mg} / \mathrm{g})$ \\
\hline 165 & 20 & 15 & 12 & 6,683 & 0.000318 & -0.9506 & 40.99 \\
\hline 165 & 20 & 15 & 12 & 7,400 & 0.000100 & -0.9367 & 45.38 \\
\hline 165 & 20 & 15 & 13 & 6,507 & 0.000356 & -0.9992 & 36.84 \\
\hline 165 & 20 & 15 & 13 & 6,387 & 0.000518 & -0.9539 & 36.16 \\
\hline 165 & 20 & 15 & 13 & 6,387 & 0.000518 & -0.9539 & 36.16 \\
\hline 165 & 20 & 15 & 15 & 5,329 & 0.000416 & -0.9153 & 26.14 \\
\hline 165 & 20 & 15 & 19 & 5,274 & 0.000415 & -0.9457 & 20.16 \\
\hline 165 & 20 & 15 & 19 & 5,274 & 0.000415 & -0.9457 & 20.16 \\
\hline 165 & 20 & 15 & 20 & 9,248 & 0.000110 & -0.9530 & 19.19 \\
\hline 165 & 20 & 15 & 20 & 8,738 & 0.000216 & -0.9765 & 32.15 \\
\hline 165 & 40 & 15 & 20 & 4,459 & 0.000515 & -0.9903 & 16.41 \\
\hline 165 & 40 & 25 & 34 & 5,320 & 0.000347 & -0.9892 & 19.19 \\
\hline 165 & 20 & 25 & 34 & 6,154 & 0.000243 & -0.9870 & 22.20 \\
\hline 80 & 40 & 25 & 34 & 4,480 & 0.000689 & -0.9911 & 16.16 \\
\hline 165 & 2 & 72 & 4,470 & 6,110 & $6.66 \mathrm{E}-05$ & -0.9435 & 0.02 \\
\hline 165 & 2 & 20 & 4,470 & 3,576 & 0.000287 & -0.9195 & 0.02 \\
\hline 165 & 2 & 40 & 4,470 & 3,644 & 0.000277 & -0.9255 & 0.02 \\
\hline 165 & 2 & 56 & 4,470 & 4,347 & 0.000468 & -0.9681 & 0.02 \\
\hline 80 & 1 & 20 & 4,470 & 8,669 & $9.6 \mathrm{E}-05$ & -0.9625 & 0.02 \\
\hline 165 & 2 & 72 & 4,470 & 9,087 & $8.29 \mathrm{E}-05$ & -0.9423 & 0.03 \\
\hline 165 & 2 & 20 & 4,470 & 5,852 & 0.000171 & -0.9228 & 0.03 \\
\hline 165 & 2 & 40 & 4,470 & 6,013 & 0.000197 & -0.9261 & 0.03 \\
\hline 165 & 2 & 56 & 4,470 & 6,584 & 0.000197 & -0.8918 & 0.03 \\
\hline 80 & 1 & 40 & 4,470 & 7,620 & $6.36 \mathrm{E}-05$ & -0.9612 & 0.03 \\
\hline 330 & 1 & 72 & 4,470 & 6,894 & $8.89 \mathrm{E}-05$ & -0.9282 & 0.02 \\
\hline 330 & 1 & 20 & 4,470 & 3,079 & 0.000229 & -0.9549 & 0.02 \\
\hline 330 & 1 & 40 & 4,470 & 4,409 & 0.00026 & -0.9669 & 0.02 \\
\hline 330 & 1 & 56 & 4,470 & 6,547 & 0.000131 & -0.8401 & 0.02 \\
\hline 80 & 1 & 56 & 4,470 & 6,727 & 0.000162 & -0.9798 & 0.02 \\
\hline 165 & 1 & 72 & 4,470 & 8,178 & 0.000111 & -0.9541 & 0.02 \\
\hline 165 & 1 & 20 & 4,470 & 3,367 & 0.000142 & -0.9386 & 0.02 \\
\hline 165 & 1 & 40 & 4,470 & 4,480 & 0.000181 & -0.9214 & 0.02 \\
\hline 165 & 1 & 56 & 4,470 & 6,270 & 0.000204 & -0.9606 & 0.02 \\
\hline 80 & 1 & 72 & 4,470 & 6,650 & 0.000259 & -0.9228 & 0.03 \\
\hline 165 & 1 & 20 & 4,470 & 3,367 & 0.000142 & -0.9386 & 0.03 \\
\hline 165 & 2 & 40 & 4,470 & 3,644 & 0.000277 & -0.9255 & 0.03 \\
\hline 165 & 2 & 56 & 4,470 & 6,584 & 0.000197 & -0.8918 & 0.03 \\
\hline 165 & 1 & 72 & 4,470 & 8,178 & 0.000111 & -0.9541 & 0.04 \\
\hline 165 & 2 & 20 & 4,470 & 3,576 & 0.000287 & -0.9195 & 0.04 \\
\hline 165 & 2 & 40 & 4,470 & 6,013 & 0.000197 & -0.9261 & 0.04 \\
\hline 165 & 2 & 72 & 4,470 & 6,110 & $6.66 \mathrm{E}-05$ & -0.9435 & 0.04 \\
\hline 165 & 2 & 20 & 4,470 & 5,852 & 0.000171 & -0.9228 & 0.04 \\
\hline 165 & 1 & 56 & 4,470 & 6,270 & 0.000204 & -0.9606 & 0.02 \\
\hline 165 & 2 & 72 & 4,470 & 9,087 & $8.29 \mathrm{E}-05$ & -0.9423 & 0.02 \\
\hline 165 & 1 & 40 & 4,470 & 4,480 & 0.000181 & -0.9214 & 0.02 \\
\hline 165 & 2 & 56 & 4,470 & 4,347 & 0.000468 & -0.9681 & 0.02 \\
\hline 165 & 2 & 27 & $8,691.25$ & 7,916 & 0.000131 & -0.9575 & 0.02 \\
\hline 165 & 1 & 107 & $8,691.25$ & 4,496 & 7.59E-05 & -0.9625 & 0.02 \\
\hline
\end{tabular}




\section{Untreated, Autohydrolized and Brine Hydrolized Spruce}

Table 6 continued

\begin{tabular}{rlllrlll}
\hline $\mathrm{Ci}$ & $\mathrm{Q}(\mathrm{mL} / \mathrm{min})$ & $\mathrm{x}(\mathrm{cm})$ & $\mathrm{m}(\mathrm{g})$ & $\mathrm{N}$ & $\mathrm{K}$ & $\mathrm{R}$ & $\mathrm{qo}(\mathrm{mg} / \mathrm{g})$ \\
\hline 165 & 1 & 137 & $8,691.25$ & 3,743 & $6.74 \mathrm{E}-05$ & -0.9760 & 0.02 \\
165 & 1 & 27 & $8,691.25$ & 10,041 & $3.08 \mathrm{E}-05$ & -0.9818 & 0.01 \\
165 & 1 & 67 & $8,691.25$ & 5,410 & $3.13 \mathrm{E}-05$ & -0.9809 & 0.01 \\
80 & 1 & 72 & 4,470 & 7,398 & $6.08 \mathrm{E}-05$ & -0.7585 & 0.02 \\
165 & 1 & 72 & 4,470 & 8,178 & 0.000111 & -0.9541 & 0.04 \\
165 & 1 & 20 & 4,470 & 3,367 & 0.000142 & -0.9386 & 0.04 \\
165 & 1 & 40 & 4,470 & 4,480 & 0.000181 & -0.9214 & 0.04 \\
165 & 1 & 56 & 4,470 & 6,270 & 0.000204 & -0.9606 & 0.02 \\
165 & 2 & 72 & 4,470 & 6,110 & $6.66 \mathrm{E}-05$ & -0.9435 & 0.02 \\
165 & 2 & 20 & 4,470 & 3,576 & 0.000287 & -0.9195 & 0.02 \\
165 & 2 & 40 & 4,470 & 3,644 & 0.000277 & -0.9255 & 0.02 \\
165 & 2 & 56 & 4,470 & 4,347 & 0.000468 & -0.9681 & 0.02 \\
165 & 2 & 72 & 4,470 & 9,087 & $8.29 \mathrm{E}-05$ & -0.9423 & 0.02 \\
165 & 2 & 20 & 4,470 & 5,852 & 0.000171 & -0.9228 & 0.02 \\
165 & 2 & 40 & 4,470 & 6,013 & 0.000197 & -0.9261 & 0.02 \\
165 & 2 & 56 & 4,470 & 6,584 & 0.000197 & -0.8918 & 0.02 \\
\hline
\end{tabular}

Table 7 Adsorption by untreated spruce.

\begin{tabular}{llllllll}
\hline $\mathrm{Ci}$ & $\mathrm{Q}(\mathrm{mL} / \mathrm{min})$ & $\mathrm{x}(\mathrm{cm})$ & $\mathrm{m}(\mathrm{g})$ & $\mathrm{N}$ & $\mathrm{K}$ & $\mathrm{R}$ & $\mathrm{qo}(\mathrm{mg} / \mathrm{g})$ \\
\hline 165 & 20 & 15 & 12 & 6,683 & 0.000318 & -0.9506 & 40.99 \\
165 & 20 & 15 & 12 & 7,400 & 0,000100 & -0.9367 & 45.38 \\
165 & 20 & 15 & 13 & 6,507 & 0.000356 & -0.9992 & 36.84 \\
165 & 20 & 15 & 13 & 6,387 & 0.000518 & -0.9539 & 36.16 \\
165 & 20 & 15 & 13 & 6,387 & 0.000518 & -0.9539 & 36,16 \\
165 & 20 & 15 & 15 & 5,329 & 0.000416 & -0.9153 & 26.14 \\
165 & 20 & 15 & 19 & 5,274 & 0.000415 & -0.9457 & 20.16 \\
165 & 20 & 15 & 19 & 5,274 & 0.000415 & -0.9457 & 20.16 \\
165 & 20 & 15 & 20 & 9,248 & 0.000110 & -0.9530 & 19.19 \\
165 & 20 & 15 & 20 & 8,738 & 0.000216 & -0.9765 & 32.15 \\
165 & 40 & 15 & 20 & 4,459 & 0.000515 & -0.9903 & 16.41 \\
165 & 40 & 25 & 34 & 5,320 & 0.000347 & -0.9892 & 19.19 \\
165 & 20 & 25 & 34 & 6,154 & 0.000243 & -0.9870 & 22.20 \\
80 & 40 & 25 & 34 & 4,480 & 0.000689 & -0.9911 & 16.16 \\
\hline
\end{tabular}

\section{Discussion}

Our study is a research on the adsorption capacity of the spruce and its application to industrial scale. There is an object for further research to determine the spruce quantity by region distribution and corresponding exploitation by industrial scale unit.

The Methylene Blue adsorption capacity for various lignocellulosic materials found in the literature was compared to the spruce adsorption capacity estimated in the present work. The adsorption capacity of the spruce was better than the adsorption capacity of other waste biomass such as peanut husk [18], turbinaria turbinate, alga [18] and wheat straw [18].

The present study is a part of continues involvement of our Research Group in the study of wastewater treatment using original and modified (pretreated) lignocellulosic biomass as potential adsorbents. Consequently, spruce is of high interest for industrial scale application, especially in wood producing countries. The use of spruce could be an answer, given its abundance as a common waste in industry and rural environment. It is therefore a challenge to find a solution to the problem of wastewater cleaning. 

Untreated, Autohydrolized and Brine Hydrolized Spruce

The search for a low cost and easily available adsorbent has led to the investigation of materials of agricultural and biological origin, along with industrial by-products, as adsorbents. So, a good support material used for immobilization should be rigid, chemically inert and cheap, and should bind cells firmly; it also should have high loading capacity and a loose structure for overcoming diffusion limitations. For continuous operation with immobilized biomass, the most convenient configuration is that of a packed column, much like that used for ion exchange. A packed bed column is an effective process for cyclic sorption/desorption, as it makes the best use of the concentration difference known to be a driving force for adsorption, allows more efficient utilization of the sorbent capacity and results in a better quality of the effluent.

\section{Conclusions}

Fixed-bed or column adsorption is the most popular option in practical application of adsorption process, and due to the complexity of a column adsorption system and the lack of solid theory, its mathematical modeling is obviously more difficult than batch adsorption. To choose or develop a suitable model, accuracy and convenience should be considered simultaneously.

Fixed bed columns systems with continuous flow allow the regenerating cycles operation. Using an appropriate effluent solution, the sorbent can be regenerate. The regeneration process liberates small volumes of concentrated metal solutions, which is more appropriate for conventional recovery processes.

Calculated breakthrough curves of the model were in approximate agreement with the experimental ones. It was established that the column behavior of this biosorbent was not entirely predictable on the basis of the simplistic Bohart and Adams model. A more detailed analysis using mass transfer models will be the subject of future communications.

The process allows treatment of a given volume of effluent by using a minimal mass of adsorbent which concentrates maximal content of dye. The adsorption breakthrough curves obtained at different flow rates indicate that an increase in flow rate decreases the treated volume to the breakthrough point and therefore decreases the service time of the bed. Lower removal capacities were observed, probably due to the fact that contact times were insufficient for the adsorption equilibrium to develop between the spruce and the dye.

However, from the literature reviewed, the sorbent used in this study was compared in term of cost with those that stand out for high absorbency such as activated carbon, fungi biomass, ion-exchange resins, marine algae. Although improved sorption capacity may compensate the cost of additional processing, it was noticed that the spruce presented a better option with a complete reusability, lower purchase price, biodegradable by-product and easy handling.

\section{References}

[1] Robinson, T., Mcmullan, G., Marchant, R., Nigam, P. 2001. "Remediation of Dyes in Textile Effluent: a Critical Review on Current Treatment Technologies with a Proposed Alternative." Bioresour: Technol. 77 (3): 247-255.

[2] Sparado, J. T., Gold, M. H., and Renganathan, V. 1992. "Degradation of Azo Dyes by Lignin Degrading Fungus Penicillium Chrysosporium." Appl. Environ. Microbiol. 58 (8): 2397-2401.

[3] Mastrangelo, G., Fedeli, U., Fadda, E., Mila, G., and Lange, J. 2002. "Epidermiologic Evidences of Cancer Risk in Textile Industry Workers: A Review and Update." Toxicol. Industr. Health 18 (4): 171-181.

[4] Song, J., Zou, W., Bian, Y., Su, F., and Han, R. 2011. "Adsorption Characteristics of Methylene Blue by Peanut Husk in Batch and Column Modes." Desalination 265 (1): 119-125.

[5] Deng, H., Lu, J., Li, G., Zhang, G., and Wang, X. 2011. "Adsorption of Methylene Blue on Adsorbent Materials Produced from Cotton Stalk." Chem. Eng. J. 172 (1): 326-334.

[6] Sohrabi, M. R., and Ghavami, M. 2008. "Photocatalytic Degradation of Direct Red 23 Dye Using UV/TiO ${ }_{2}$ : Effect of Operational Parameters." J. Hazard. Mater. 153 (3): 1235-1239.

[7] Ciardelli, G., Corsi, L., and Marcucci, M. 2001. "Membrane Seperation for Watewater Reuse in the Textile Industry." Resour. Conserv. Recycl. 31 (2): 


\section{Fixed-bed-column Studies in Laboratory and Pilot Scale for Methylene Blue Removal and Recovery by 497 Untreated, Autohydrolized and Brine Hydrolized Spruce}

189-197.

[8] Tang, H., Yin, L., and Lu, H. 2012. "Synthesis, Conformations and Cell-Penetrating Properties." Biomacromolecules 13 (7): 2609-2015.

[9] Rafatullah, M., Sulaiman, O., Hashim, R., and Ahmad, A. 2010. "Adsorption of Methylene Blue on Low-cost Adsorbents: A Review." J. Hazard. Mater. 177 (1): $70-80$.

[10] El-Sayed, A. M., Mitchell, V., Manning, L. A., Cole, L., and Suckling, D. M. 2011. "New Sex Pheromone Blend for the Lightbrown Apple Moth, Epiphyas Postvittana." J. Chem. Ecol. 37 (6): 640-646.

[11] Altenor, S., Ncibi, M. C., Emmanuel, E., and Gaspard, S. 2012. "Textural Characteristics, Physiochemical Properties and Adsorption Efficiencies of Caribbean Alga Turbinaria Turbinata and Its Derived Carbonaceous Materials for Water Treatment Application." Biochem. Eng. J. 67: 35-44.

[12] Liu, T., Li, Y., Du, Q., Sun, J., Jiao, Y., Yang, G., et al. 2012. "Adsorption of Methylene Blue from Aqueous Solution by Grapheme, Colloids and Surf." $B$ : Biointerfaces 90: 197-203

[13] Al-Anber, Z. A., Al-Anber, M. A., Matouq, M., Al-Ayed, O., and Omari, N. M. 2011. "Defatted Jojoba for the Removal of Methylene Blue from Aqueous Solution:
Thermodynamic and Kinetic Studies." Desalination 276 (1): $169-174$

[14] Theydan, S. K., and Ahmed, M. J. 2012. "Adsorption of Methylene Blue onto Biomass-based Activated Carbon by $\mathrm{FeCl}_{3}$ Activation: Equilibrium, Kinetics, and Thermodynamic Studies." J. Anal. Appl. Pyrol. 97: 116-122.

[15] Malekbala, M., Hosseini, S., Yazdi, S. K., and Masoudi, S. S. 2013. "The Study of the Potential Capability of Sugar Beet Pulp on the Removal Efficiency of Two Cationic Dyes." Chem. Eng. Res. Des. 90 (5): 704-712.

[16] Ahmed, M. J., and Dhedanb, S. K. 2012. "Equilibrium Isotherms and Kinetics Modeling of Methylene Blue Adsorption on Agricultural Wastes-based Activated Carbons." Fluid Phase Equilibr. 317: 9-14.

[17] Oliveira, W. E., Franca, A. S., Oliveira, L. S., and Rocha, S. D. 2008. "Untreated Coffee Husks as Biosorbents for the Removal of Heavy Metals from Aqueous Solutions." J. Hazard. Mater. 15 (3): 1073-1081.

[18] Reffas, A., Bernardet, V., David, B., Reinert, L., Bencheikh, L. M., Dubois, M., et al. 2010. "Carbons Prepared from Coffee Grounds by $\mathrm{H}_{3} \mathrm{PO}_{4}$ Activation: Characterization and Adsorption of Methylene Blue and Nylosan Red N-2RBL." J. Hazard. Mater. 175 (1): 779-788. 